\title{
Women Empowerment through IFAD's Rural Development Project
}

\author{
Dr. Hind Bushra Ahmed Ibrahim \\ School of Rural Extension Education and Development (REED) \\ Ahfad University for Women, Omdurman, Sudan
}

\begin{abstract}
Rural women play a crucial role in agricultural development and allied fields. In the present study an attempt has been made to analyse the influence of IFAD rural development project on women empowerment. The results showed that majority of the women had medium or low level of education and they play important role in agricultural production in their area. Most of them participated in agricultural training and were agreed upon the suitability of training methods.
\end{abstract}

Keywords: Empowerment

\section{INTRODUCTION}

Around the world, resilient and resourceful rural women contribute in a multitude of ways through different livelihood strategies to lifting their families and communities out of poverty. They work as unpaid and own-account 1 or self-employed 2 on-farm and non-farm labourers; as on- and non-farm wage labourers for others in agriculture and agro-industry; as entrepreneurs, traders, and providers of services; as leaders; as technology researchers and developers; and as caretakers of children and the elderly (FAO 2011a). Rural women work long hours and many of their activities are not defined as "economically active employment" in national accounts but are essential to the well-being of their households (FA0, 2011a). They also constitute a significant proportion of the labor on their family farms - whether producing for household consumption or for enterprise or both (UNIFEM, 2005) Rural women are constrained by unequal access to productive resources and services and inadequate or inaccessible infrastructure. The limitations rural women face in turn impose huge social, economic, and environmental costs on society as a whole and rural development in particular including lags in agricultural productivity.

The term empowerment has different meanings in different sociocultural and political contexts, and does not translate easily into all languages.

Empowerment is a process that helps people have a sense of ownership over a project being implemented in their area. In this way the international development community attempts to improve the poverty situations of developing countries and set up the basis for future self-help programs. Empowering communities will help communities in the future to have less reliance on external forces to help them beat poverty.

"Empowerment is the expansion of assets and capabilities of poor people to participate in, negotiate with, influence, control, and hold accountable institutions that affect their lives "(Narayan. 2002. Xviii). 
According to UN, Women's empowerment has five components: women's sense of self-worth; their right to have and to determine choices; their right to have access to opportunities and resources; their right to have the power to control their own lives, both within and outside the home; and their ability to influence the direction of social change to create a more just social and economic order, nationally and internationally.

The International Fund for Agricultural Development (IFAD) was established in 1977 to alleviate poverty and improve the nutritional level of the poorest populations in developing countries through lending, primarily on highly concessional terms. The Fund's primary objective was increased food production by smallholders, and this remains central, but within a broadened vision of rural development that includes those who do not own or have access to land. During the last twenty years, IFAD has financed a total of 489 projects in developing countries throughout the world. A gender perspective looks at how and why men and women experience poverty differently and become poor through different processes and, in turn, how rural development presents different opportunities and risks for men and women. The Fund's gender strategy recognizes the importance of rural poor women's roles in crop, livestock, fishery and microenterprise activities and the links between rural women's economic activities and household food security (HFS). It addresses the following realities:-

- Women represent the majority of the rural poor (up to 70\%), especially where migration, marital instability, male mortality and single parenthood have left them as heads of households;

- Women carry most of the responsibility for household food security;

- Women have indigenous technical knowledge, skills and motivation; and

- Women tend to remain on the margin, without access to critical resources (IFAD1998).

The main aim of this paper is highlights the role of IFAD's rural development project on women empowerment with emphasis on the type of project activities and approaches of implementation.

\section{METHODOLOGY}

The study was conducted in Southern Kordofan State (Abassia Tagali locality). The main target group of this study were women who participate in IFD project. The researcher purposively selected 50 women from all as a sample size. Primary data was collected by using quantitives tool (questionnaire). 


\section{Demographic information of respondent}

\section{RESULTS AND DISCUSSION}

\begin{tabular}{|l|l|l|}
\hline Age & Frequencies & $\%$ \\
\hline $15-25$ & 9 & 18 \\
\hline $26-36$ & 17 & 34 \\
\hline $37-46$ & 12 & 24 \\
\hline $47-57$ & 9 & 16 \\
\hline Above 57 & 3 & 6 \\
\hline Total & 50 & 100 \\
\hline \multicolumn{2}{|l|}{} \\
\hline $\begin{array}{l}\text { Education } \\
\text { level }\end{array}$ & \multicolumn{2}{|l|}{} \\
\hline Illiterate & 19 & 38 \\
\hline Basic & 18 & 36 \\
\hline secondary & 13 & 26 \\
\hline Total & 50 & 100 \\
\hline \multicolumn{2}{|l|}{} \\
\hline Marital status & \multicolumn{1}{|l|}{} \\
\hline Single & 5 & 54 \\
\hline Married & 27 & 10 \\
\hline Widowed & 14 & 28 \\
\hline divorced & 4 & 8 \\
\hline Total & 50 & 100 \\
\hline
\end{tabular}

Table (1) Demographic information of respondent

In terms of the ages of the respondents, the survey findings showed that most of them (92\%) in the active age this indicate that, there have ability acquired new knowledge and skills. In terms of education, the majority (62\%) of them have little base of formal education, which is the most important human capital in terms of livelihood operation. This is supported by Rakodi and Jones (2002),

"Lack of human capital in the form of skills and education affects the ability to secure a livelihood quite directly in both urban and rural areas

\section{Source of livelihood of respondents}

\begin{tabular}{|l|l|l|}
\hline Source of livelihood & Frequencies & $\%$ \\
\hline Agriculture & 42 & 84 \\
\hline Agriculture +Trades & 8 & 16 \\
\hline Total & 50 & 100 \\
\hline
\end{tabular}

Table (3) source of livelihood of respondents

From result above, the main source of livelihood is agricultural activities (livestock and rainfed agriculture). Around $84 \%$ of the respondents were involved in agricultural activities dependence on rain -fed agriculture is very common amongst the communities of the study area and, this may be attributed to the geographic location of the study area which lies in the semi-arid zone of Sudan.This result indicated that, Women are not only the major source of labour in the agricultural sector, they are also responsible for the vital tasks of caring for children, the sick and the elderly as part of their household responsibilities. Women continue to play a vital role in agricultural development hence the need to recognize their role and enhance their capabilities to improve on agricultural productivity. This is supported (Kabira, 1997).

"Therefore, the design of extension activities needs to take these roles into consideration so that they are not in conflict with time for other roles" 
Also, livelihood strategies for these women are mainly based on the use of natural resources; this led too little chance for searching other options which are for them is limited before the training offered by the IFD organization.

\begin{tabular}{|l|l|l|}
\hline Mechanism & Frequencies & $\%$ \\
\hline Self-initiative & 10 & 20 \\
\hline IFAD - initiative & 25 & 50 \\
\hline Local Committee & 15 & 30 \\
\hline Total & 50 & 100 \\
\hline
\end{tabular}

Table (4) Mechanism of respondents' Involvement in IFD project

The result above showed that, the main motivation factor of half of respondents to involve in IFAD project was organization initiative, the other were distributed between self and local committee initiative.

Result was indicate that there were community and self-interest to participate in this project. Agricultural production is one of the strategies that has been adopted by many countries globally especially in Sub Saharan Africa. Therefore, productive resources that substitute agricultural production need to be available to women in terms of accessibility and control to address their needs.

\begin{tabular}{|l|l|l|}
\hline Activities & Frequencies & $\%$ \\
\hline Agricultural training workshop & 30 & 60 \\
\hline $\begin{array}{l}\text { Vocational training (handcrafts- } \\
\text { making pots) }\end{array}$ & 6 & 12 \\
\hline Adult education & 4 & 8 \\
\hline Participating on all projects & 10 & 20 \\
\hline Total & 50 & 100 \\
\hline
\end{tabular}

Table (5) Project activities which respondent involved in

The IFAD aim at improving the socio- economic situation of rural women in the project area through village training, Women trained to obtain the essential skills and knowledge to manage their income-generating activities. Regarding project's activities, more than $60 \%$ of women were involved in agricultural training and the rest of ranged between vocational training and adult education. This result indicate that, the organization was caring about the needs and interests of women because in developing countries, where a majority of families derive their livelihoods from agriculture, sustainable agriculture. Most of them they were lack of new knowledge and information. This agreed with (Altieri 2002a).

"In many developing countries, agriculture is a main source of livelihoods for a majority of the population, but making it sustainable is still a challenge. Poverty, lack of access to adequate farm inputs, information, training and markets, as well as policy failures, infrastructural and institutional shortcomings are among the major items that threaten farming sustainably".

\begin{tabular}{|l|l|l|}
\hline Activities & Frequencies & $\%$ \\
\hline Improvement seeds & 10 & 25 \\
\hline Appropriate technology & 6 & 15 \\
\hline Both & 24 & 60 \\
\hline Total & 40 & 100 \\
\hline
\end{tabular}

Table (6) Types of Agricultural training workshop

From result above, 60\% of respondents were participated in two types of agricultural training, which mean most of women needs and interested for theses training. So that each 
development projects do best when women's roles and needs are factored into project design from the start. Also in fact that, Women's preferences for crop varieties differ from that of men. Women elect to produce types or varieties which are mainly used for domestic consumption, whereas men prefer crop varieties which have high market demand and fetch high prices. This result agreed with

"Women play a major role in food production in the developing world-contributing as much as 60 percent of labor on family farms in Sub-Saharan Africa, for example-but they often have no control over farm income or agricultural resources such as seeds, fertilizer, and land"

\begin{tabular}{|l|l|l|}
\hline Means & Frequencies & $\%$ \\
\hline Field work(practical) & 14 & 35 \\
\hline Focus discussion & 6 & 15 \\
\hline Both & 20 & 50 \\
\hline Total & 40 & 100 \\
\hline
\end{tabular}

Table (7) Means of Training

From table above, it's clear that the main methods that used for training are two field work and group discussion. This result indicated that, participatory approach was used in this training to know the women needs .Participatory approaches which have been used to articulate the women farmers' demands have enabled women to demand enterprises that they are entitled to without any opposition (Charman, 2008).

\begin{tabular}{|l|l|l|}
\hline Suitability & Frequencies & $\%$ \\
\hline Yes & 35 & 87.5 \\
\hline No & 5 & 12.5 \\
\hline Total & 40 & 100 \\
\hline
\end{tabular}

Table (7) Suitability and benefits of training and its means for respondents:

The result above show that, most women were agreed upon the suitability of training methods. This result indicated that, the importance of selection regarding method of training it's depend upon two factors type of training and capability of target group. The field work provide an opportunity to apply previous knowledge, view real examples set in a experienced framework, and opportunity to be involved, physically, with real situations in the field. All of this promotes a deeper understanding of the subject being studied and an improved ability to remembrance the information and experiences when they needed.

Women now make up the majority of the agricultural sector in developing countries, but recent evidence suggests that not only is their productivity constrained by a lack of appropriate skills training (Danida, 2004), but also that they are particularly vulnerable to environmental changes (Aguilar, 2009

\begin{tabular}{|l|l|l|}
\hline Benefits & Frequencies & $\%$ \\
\hline $\begin{array}{l}\text { Increase field production+ Improvement } \\
\text { in their skills and capabilities+ Increase in } \\
\text { their income and standard of living+ self- } \\
\text { confident + contribution in decision making }\end{array}$ & 50 & 100 \\
\hline Total & 50 & 100 \\
\hline
\end{tabular}

Table (8) Benefits from IFAD project

The positive influence of the project of the IFAD project for rural development on the women empowerment s was observed in the improvement of their agricultural skills, self - confidence and participation on family decision making. This result indicated that, the project was 
promoting women confidence and skills which increased women's power on decision making. That there have been significant improvements in land productivity.

\section{CONCLUSION}

It is found that, before IFAD project, the livelihood pattern of farmer women was very simple. After project, big changes happened in the farmer women. It can be said that, the project activities has had positive effects on the livelihood of them for example, the economic situation of the women strongly improved due to project activities. Moreover, most women became professional in agriculture and new sources for generating income were increased according to new skills and increased in women's power on decision making.

\section{References}

Altieri, M. A. 2000. Multifunctional dimensions of ecologically-based agriculture in Latin America. International Journal of Sustainable Development \& World Ecology 7(1): 62-75.

Charman, A. (2008). Empowering women through livelihoods oriented agricultural service provision. A Consideration of Evidence from Southern Africa. Research Paper No 2008/1.UNU World Institute for Development Economics Research

FAO (2011a). The State of Food and Agriculture, 2010 - 2011. Rome: FAO.

IFAD 1998. RURAL women in IFAD's projects the key to poverty alleviation

Kabira, W. (1997). Gender training of trainers: An introduction. A publication of collaboration for gender and development. Kenya:CCGD.

-Kathleen Collett \& Chris Gale, 2009 Training for Rural Development: Agricultural and Enterprise Skills for Women Smallholders , Produced by: City \& Guilds Centre for Skills Development, 24-30 West Smithfield, London, Narayan, Deepa, (ed). 2002. Empowerment and Poverty Reduction: A Sourcebook. The World Bank. Washington D.C.

UNIFEM (2005). Progress of the World's Women 2005. UNIFEM

United Nations population information network (POPIN) 1998, Guidelines on Women's Empowerment. 